The Electrodeless Discharge in Sodium Vapour.

By placing a primary Tesla coil about a highly exhausted pyrex bulb containing metallic sodium, and enclosing the whole in an oven, the writer has obtained a brilliant electrodeless discharge at a temperature in the neighbourhood of $300^{\circ} \mathrm{C}$. Observation with a Hilger constant deviation spectroscope revealed, in addition to the $D$ lines, doublets at 6162 (and 6158), at 5688 (and 5683 ), at 4667 , at 4497 , as well as faint probable doublets at 5153 , at 4980 , and at 4572 -lines all to be found in the arc spectrum. After two or three hours' continuous heating the discharge was almost as brilliant as initially, although the bulb on removal from the oven had the usual brown colour resulting from the action of the hot vapour.

The writer has under way a further study of this type of discharge with sodium and with other metallic vapours, and hopes that with more violent excitation than was used in the above case interesting spectroscopic data may be obtained.

JOHN K. ROBERTSON.

Queen's University, Kingston, Canada, April 7 .

\section{High-speed Aircraft Propellers and the Destruction of} Gnats.

SOME of your readers may be interested in an incident which took place during the testing of a propeller at the Royal Aircraft Establishment, South Farnborough. The propeller was being revolved at a very high speed, such that the tips of the blade were moving at about Iooo ft. per second. The test was carried out in the open, and the noise was such that in the neighbourhood of the propeller it was impossible to make oneself heard. Moreover, the noise gave an unpleasant physiological sensation. The interesting fact to your readers is that apparently this noise attracted very large numbers of gnats, and most of these lost their lives by being drawn through the propeller, which on being stopped was found to be covered with their blood and portions of their bodies.

At the commencement of the test, and even when runining with a tip-speed of $800 \mathrm{ft}$. per second, there was no sign of any fiying insects, nor was the day such that one would expect them.

I have been present at many such tests, though never at such a high speed, but I have not noticed such an occurrence before.

April 21.

\section{Why do Worms Die?}

The Rev. H. Friend's letter in Nature of April 7 recalls an observation made towards the end of last November with respect to the death of worms. A shallow gutter or water-drain by the side of a road near Sidmouth had become filled with dead leaves (principally of Populus alba) during the late autumn. These by accumulation and pressure had formed a firm, compact bed in the drain. During a night at the end of November last we had exceptionally heavy rain, and the next morning, on passing along the road in the forenoon, my attention was immediately arrested by the number of worms (of several species) lying dead outside the shallow water-drain. In the space of about $20 \mathrm{ft}$. I counted upwards of a hundred worms. They had evidently crawled out from the bed of dead leaves to the firm surface of the road and died there. My conclusion was that they had crawled out from the gutter in a half-drowned condition and beyond the chance of recovery. A curious point was that they all (irrespective of size and species) appeared to have crawled to about the same distance, so that they formed a fairly even line running parallel with the gutter.

G. 'T. HARRIS.

\section{Vegetation around London Earlier than in the Provinces.}

Nature of April 2I, in the Notes columns, p. 245, mentions that a correspondent who travels frequently from the south-west of England to London finds at this time of year vegetation, notably the flowering trees, generally more advanced as the metropolis is approached. In the past I have frequently noticed the spring vegetation in London to be more forward than thirty or forty miles outside. Commonly, in visiting East Grinstead from London, I have noticed and remarked on the lateness of spring vegetation compared with the metropolitan suburbs. This year at Tulse Hill, and generally in the south of London, the pearand apple-trees were in fairly full blossom at the commencement of March, whilst at Eastbourne similar vegetation was fully three weeks later. The dates from the Phenological Report for IgI9 published by the Royal Meteorological Society referred to in your Note can scarcely claim to determine the general difference between south-west and south-east England. The early months of rgig were abnormally cold and wet, and on April 27 a snowstorm of considerable severity occurred in the south of England.

Chas. HaRding.

2 Bakewell Road, Eastbourne, April 2 I.

\section{A Modern Inorganic Chemistry.}

IN a very able and courteous review of my "Textbook of Inorganic Chemistry" which appeared in NATURE of April 14, "A. J. A." makes two statements which I think might be misleading to many readers. He states that "in practice calcium cyanamide is not produced in an arc furnace." The Stockholms Superfosfat Fabriks Aktiebolag, Stockholm, make 20,000 tons of cyanamide annually in arc furnaces, and since this modern so-called "continuous cyanamide process" is referred to most respectfully in the report of the Nitrogen Products Committee, I thought it worthy of mention-in an imperfect manner, it is true. It is quite possible that of the two cells described for the manufacture of electrolytic alkali, one is "obsolete" and the other "obsolescent." It is five years since I saw one described in some text-books as "quite obsolete" operating with great activity; doubtless it has now gone out of use. Since these two cells, however, were the only ones I could find authoritatively described as in use, or as having been in use, in this country, I preferred to describe them rather than cells existing only in patent specifications. J. R. Partington.

My knowledge of the continuous cyanamide process is confined to what appears in the Nitrogen Products Committee's report, and I am afraid I did not know that the preliminary heating of the carbide necessary before it can absorb nitrogen was carried out by electric arc heating. The arc itself is, of course, at a temperature far above that at which nitrogen can be absorbed by carbide.

With reference to Prof. Partington's second point, there is nothing in his description of electrolytic alkali cells to indicate that he is only dealing with processes used in this country, and there is no lack of authoritative descriptions of cells used abroad, where electrolytic alkali has assumed greater importance than has been the case here in the past. Even so, I think I am right in saying that the Castner-Kellner rocking cell is no longer used to produce alkali for the market, and, this being so, it appears a pity to devote to it such a disproportionate amount of attention. "Obsolescent" is, I imagine, a fair description of the Hargreaves-Bird cell. No. 2687 , VOL. IO 7]. 